\title{
REPORT OF THE WORKING GROUP ON LEGISLATION AND EDUCATION
}

\author{
Alejandro Arias, Jesuina da Rocha, Heidi W. Weiskel, Lilia Fidelix, Cristian De Haro, Marta Cremer, Marila Lázaro, \\ and Salvatore Siciliano
}

It is suspected that the franciscana is the cetacean species in the western South Atlantic with the most conservation problems, which occur throughout the species entire range. Incidental captures in coastal fishing nets, contamination, habitat destruction, and overfishing are the most common problems this species confronts. But most importantly, the general lack of knowledge about the species on the part of the public, lawmakers, fishermen and even members of the scientific community, has enabled the franciscana to go unnoticed. Thus, today there is no conservation program or legislation that assures its conservation.

In order to draft this document, an exhaustive study was undertaken of each of the existing pieces of legislation in Brazil, Uruguay and Argentina that could be linked, directly or indirectly, to the protection and conservation of the franciscana.

All of the compiled information can be found in Annex I, where the number and a summary of the text of each legal document (e.g., law, resolution, decree) are listed together. The pieces of legislation whose content is potentially useful from the legal point of view, with regard to the management and conservation of the franciscana, have been highlighted in grey. There are laws that are local and regional in scope, others with a broader national mandate and still others that operate at the international level.

From a quick survey of the legislation of the three countries, it is evident that there are many laws, decrees, and resolutions that cover protection and management of aquatic fauna. In spite of this, the most urgent problem is the lack of enforcement of existing laws on the part of the responsible agencies and parties.

Education programs for the franciscana or marine mammals in general, which are a fundamental pillar of conservation, are also lacking in Brazil, Uruguay and Argentina.

In Argentina, the Cethus Foundation (Fundación Cethus) together with CEANSE $^{1}$, has been organizing an educational program whose central focus is the franciscana. The objectives and outline for this project are described in Annex II.

In addition, the AquaMarine Foundation (Fundación AquaMarine), with the support of international nongovernmental organizations and the backing of the Department of Fish and Aquatic Resources under the Secretary of Sustainable Development and Environmental Policy in the federal government of Argentina, is putting together an educational program for both the short and long term. The program was launched in December 2001. The principal objective of this program is to spread information about the biology and conservation status of the franciscana throughout the range of its distribution along the Argentine coast, focusing efforts during the first year in the localities of San Clemente del Tuyú, San Bernardo, La Lucila, Santa Teresita, Mar del Plata, Bahía Blanca and Bahía San Blas (Buenos Aires Province).

\section{ANNEX I}

Summary of Argentine, Uruguayan and Brazilian legal instruments, which directly or indirectly protect marine mammals and the surrounding waters under the governmental bodies' respective jurisdictions. (N.B. This list is not meant to be exhaustive.)

\section{BRAZILIAN LEGISLATION}

Law $\mathrm{N}^{0} 7.643 / 1987$

Prohibits the direct harvest or any type of intentional harassment of all cetacean species found in waters under federal jurisdiction.

\section{Law $\mathrm{N}^{0} 9.605 / 1998$}

Lays out punitive sanctions and administrative consequences resulting from conduct harmful to the natural environment.

\section{Directive $\mathrm{N}^{\circ} \mathrm{N}-11 / 1986$}

Prohibits the harassment, hunting, harvest and capture of small cetaceans, pinnipeds and sirenians in waters under federal jurisdiction.

\section{Directive No $1.522 / 1989$}

Recognizes a list of Brazilian fauna species threatened with extinction. Among the species included are the following species of marine mammals: Southen right whale (Eubalaena australis), humpback whale (Megaptera novaeangliae), franciscana (Pontoporia blainvillei), Amazonian manatee (Trichechus inunguis), West Indian manatee (Trichechus manatus), long-tailed otter (Lutra longicaudis) and giant Brazilian otter (Pteronura brasiliensis).

\section{Directive $N^{\circ} 2.306 / 1990$}

Prohibits all forms of intentional harassment for all cetacean species in waters under Brazilian jurisdiction.

\section{Directive $N^{\circ}$ 5/1995}

Establishes regulations for the protection of the spinner dolphin (Stenella longirostris) in the areas where it reproduces and raises its young in Fernando de Noronha, an area with heavy tourist activity.

\section{Directive $N^{\circ}$ 117/1996}

Regulates tourist activities related to whalewatching in waters under Brazilian jurisdiction. 


\section{Directive $\mathrm{N}^{\circ}$ 5-N/1998}

Creates regulations for the protection of Tucuxi (Sotalia fluviatilis) within the Protected Environmental Area of Anhatomirim, with respect to the use of vessels, in accordance with Federal Decree No 528 of 20 May 1992.

\section{Directive $N^{\circ}$ 143-N/1998}

Institutes a National Centre of Research, Conservation and Management of Aquatic Mammals, with the goal of undertaking, coordinating and promoting studies at the national level on the conservation and management of aquatic mammals.

Directive of the Environmental Management Secretariat of Latin America $N^{\circ}$ 01/1998

Presents a list of fauna species from the Rio de Janeiro region threatened with extinction. This list includes the franciscana (Pontoporia blainvillei).

\section{Directive $N^{\circ} 039 / 2000$}

Forms a Network in the Northeast region, between the States of Piauí and Bahia.

\section{Directive $N^{\circ}$ 98/2000}

Regulates the maintenance of marine mammals in captivity.

\section{Decree $N^{\circ}$ 528/1992}

Creates a protected environmental area (APA) for Anhatomirim, in the State of Santa Catarina, with the goal of protecting the resident population of the Tucuxi (Sotalia fluviatilis), in its feeding and reproductive areas.

\section{Decree s/N\%/1997}

Creates a protected environmental area for the coast of Corais, in the states of Alagoas and Pernambuco (Northeast Region), which has as principal objectives the maintenance of the integrity of the habitat and preservation of the population of the West Indian manatee (Trichechus manatus).

\section{Decree s/No $/ 2000$}

Designates the coastal region of the State of Santa Catarina as a protected area for the southern right whale, (Eubalaena australis).

\section{Decree $N^{0} 171 / 1995$ of the State of Santa Catarina}

Recognizing the southern right whale (Eubalaena australis) as a Natural Monument.

\section{URUGUAYAN LEGISLATION}

\section{Law $\mathbf{N}^{0} 16.062$}

Approves the adherence of the federal government of Uruguay to the Convention on the Conservation of Migratory Species of Wild Animals (CMS).

\section{Law $N^{0} 16.211$}

States that the National Fisheries Institute is responsible for the conservation and preservation of marine mammals under Uruguayan jurisdiction.

\section{Law $\mathrm{N}^{0} \mathbf{1 7 . 2 3 4 / 2 0 0 0}$}

Protection to three maritime natural areas for the southern right whale (Eubalaena australis).

\section{Decree No $149 / 1997$}

Addresses aquatic fishing and hunting.

\section{Decree $N^{\circ} 238 / 1998$}

Adopts measures for the protection and conservation of marine mammals in Uruguayan waters.

\section{ARGENTINE LEGISLATION}

\section{Law $N^{0} 21.676 / 1978$}

Provides for the implementation at the national level of the Convention for the Conservation of Antarctic Seals.

\section{Law $\mathrm{N}^{\circ} 22.344 / 1980$}

Implements Convention of International Trade in Endangered Species of Wild Fauna and Flora (CITES) by regulating the trade of wild fauna and flora at the national level.

\section{Law $N^{0} 22.421 / 1981$}

Addresses the conservation of wildlife under national jurisdiction.

\section{Law $\mathrm{N}^{\circ} 22.584 / 1982$}

Provides for the implementation at the national level of the Convention on the Conservation of Antarctic Marine Living Resources (CCAMLR).

\section{Law $N^{\circ} 23.094 / 1984$}

"Natural Monument for the Southern Right Whale."

Designates the maximum protection that the Federal Congress can give to a flora or fauna species. The administrating body is the Administration of National Parks.

\section{Law $N^{\circ} 23.918 / 1991$}

Ratifies the Convention on the Conservation of Migratory Species of Wild Animals (CMS).

\section{Law $\mathrm{N}^{0} 23.968 / 1991$}

Establishes the extent of Argentine territorial seas as stretching from the shore out to 12 nautical miles and reinforces the role of the federal government in the protection of the natural resources in those areas.

\section{Law $\mathrm{N}^{\circ} 24.216 / 1993$}

Protection of the environment in Antarctica 


\section{Law $\mathbf{N}^{\circ} 24.375 / 1994$}

Implements the Convention on Biological Diversity (CBD) at the national level.

\section{Law $\mathrm{N}^{\circ} 24.292 / 1994$}

Implemenst the National law of Hydrocarbon.

\section{Law No $24.543 / 1995$}

Implements the United Nations Convention on the Law of the Sea (UNCLOS) at the national level.

\section{Law $\mathrm{N}^{\circ} 24.922 / 1998$}

"The National Fishing Law"

Addresses all fishing and related issues in waters under Argentine jurisdiction.

\section{Law $N^{\circ} 25.052 / 1998$}

"Law on killer whale conservation"

Prohibits the capture, sale, and placement in captivity of killer whales (Orcinus orca).

\section{Law $\mathrm{N}^{\circ} 25.260 / 2000$}

Implements the protocols of the Antarctic Treaty.

\section{Law No $25.577 / 2002$}

Prohibits the hunting and capture of all cetacean species listed in Annex I (which include all species likely to occur in Argentine waters) in all Argentine waters, including provincial waters covered by compatible legislation and the Exclusive Economic Zone (i.e., from the shore out to 200 nautical miles). Specifically, the law prohibits both the hunting and intentional capture of all listed cetaceans in nets, other fishing gear, or by other means. The law is under the jurisdiction of the Secretary of Sustainable Development and the Environmental Policy, within the Ministry of Social Development and Environment. The law also requires that measures be taken to reduce incidental captures of the species listed in Annex I.

\section{Decree No ${ }^{\circ}$ 125.258/1938}

Regulates whaling. It bans hunting of the southern right whale and of cows and calves of any species.

\section{Decree $N^{\circ} 3.142 / 1946$}

Implements the International Convention for the regulation of whaling.

\section{Decree $N^{\circ} 1.347 / 1997$}

Authorizes the application of the national Biological Diversity Law.

\section{Decree $N^{0} 1.408 / 1999$}

Transfers the authority, obligations and agreements of the International Whaling Commission (IWC) at the federal level to the Secretary of Sustainable Development and Environmental Policy.

\section{Resolution No 351/1995}

Prohibits the hunting, capture or appropriation and transit, in waters under federal jurisdiction, for all of the cetaceans and pinnipeds that appear in Appendix I. It contemplates exceptions for scientific or educational purposes. It approves the regulations for the facilities that have marine mammals.

\section{Arrangement $N^{\circ} 87 / 2000$}

Provides for the implementation at the national level of the Antarctic Treaty.

\section{Ordinance $\mathrm{N}^{\circ} \mathbf{1 0} / 1997$}

Designs special protection zones in the coast, where is it forbidden to unload any kind of hydrocarbon or waste that might pollute the marine environment.

\section{Ordinance $N^{\circ} 11 / 1997$}

Determines the maritime routes of those ships transporting hydrocarbon or liquid noxious substances in bulk, establishing that they must keep a minimal distance to the coast of 20 nautical miles between Rio de la Plata (San Antonio Cape) and Lemaire Straight (San Diego Cape).

\section{Recommendation $\mathrm{N}^{\circ} \mathbf{1 0} / \mathbf{2 0 0 0}$}

Proposes the title of the southern right whale to be "the whale of Mercosur" within the MERCOSUR ("Common Market of the South").

\section{- Buenos Aires Province (BAP)}

\section{Law $\mathbf{N}^{\circ} \mathbf{1 1 . 7 2 3 / 1 9 9 5}$}

Addresses the protection, conservation, improvement and restoration of natural resources and the natural environment in general within the jurisdiction of the BAP.

\section{Decree $N^{\circ} 3.237 / 1995$}

Implements the Fishing Law of Buenos Aires Province 11.477/1994. Annex III refers to the management of aquatic mammals in captivity.

\section{- Río Negro Province}

\section{Law No $2.056 / 1985$}

Law of Fauna; it adds several species of cetaceans and pinnipeds to the list of protected species.

\section{Law N $\mathrm{N}^{0}$ 1.960/1995}

Declares an interest at the provincial level in research, protection, conservation, promotion and development of biological resources from the freshwater or marine environment.

\section{Law $\mathrm{N}^{0} 3.211 / 1998$}

Creates a Natural Protected Area at Puerto Lobos, which is characterized by the presences of sea lions, whales, birds and is the site of ongoing archaeological and palentological research.

\section{Regulatory Decree No 822/1998}

Defines maritime hunting as: "All actions undertaken with the objective of capturing cetaceans, pinnipeds, sea turtles and seabirds". 
- Chubut Province

Law No $N^{\circ}$.238/1974

Creates the Marine Provincial Park of the San José Gulf.

\section{Law $N^{0} 2.381 / 1984$}

Restricts activities with mammals.

\section{Law $\mathbf{N}^{\circ} 2.618 / 1984$}

Modifies Law $\mathrm{N}^{\circ} 2381$.

\section{Law $\mathbf{N}^{\circ} 3.257 / 1989$}

"Law of Fauna." It justifies the importance of the administration of fauna resources by promoting knowledge of their conservation and use.

\section{Law $\mathbf{N}^{\circ} 4.098 / 1996$}

Extends the zoning jurisdictions from Punta Pardela to Punta Arco.

\section{Law No $N^{\circ} .597 / 2000$}

Prohibits the capture of marine mammals in waters and coastline which are under the jurisdiction of the province. It also establishes conditions for carrying out the rescue and rehabilitation of stranded marine mammals.

\section{Decree $N^{\circ}$ 916/1986}

Implements Laws $\mathrm{N}^{\circ} 2.381$ and 2.618.

\section{Resolution N ${ }^{\circ}$ 111/1997}

Prohibits certain vessels from entering the Playa Pardelas zone during the season when whales are present.

\section{- Santa Cruz Province}

Law $\mathbf{N}^{\circ}$ 2.373/1994

Provincial Law of Wild Fauna.

\section{Law $N^{\circ} 2.582 / 2001$}

Declares the Commerson's Dolphin Cephalorhynchus commersonii as a "Natural Provincial Monument".

\section{- Tierra del Fuego Province}

\section{Law N ${ }^{0} 101 / 1993$}

Prohibits the capture, commercialisation, and industrialized use of pinnipeds and cetaceans, among other animals.

\section{Law No 176/1994}

Prohibits approaching any species of marine mammal and birds nesting areas that are under the jurisdiction of the province, without an authorization of the Application Authority.

\section{- General Pueyrredón Municipality - Buenos Aires Province}

\section{Ordinance $N^{\circ}$ 9.702/1994}

"Regulations for the authorization and operating of facilities that house marine mammals."

\section{INTERNATIONAL CONVENTIONS AND ORGANIZATIONS}

Convention on the Conservation of Migratory Species of Wild Animals (CMS)

The franciscana (Pontoporia blainvillei) is listed in Appendix I. Argentina and Uruguay adhere to this Convention.

\section{World Conservation Union (IUCN)}

Currently categorizes the franciscana (Pontoporia blainvillei) as "Data Deficient" in the 2000 IUCN Red List of Threatened Species.

\author{
ANNEX II \\ Franciscana Dolphin Campaign \\ (Fundación Cethus - C.E.A.M.S.E.) \\ Environmental Education Campaign:
}

Goals

1) Increase the level of knowledge of children and the public in general on the franciscana dolphin and the problems of marine mammal and marine resource conservation.

2) Inspire in children, young people and their families an interest in the franciscana and collaborate with them on finding solutions to the problems that have befallen this species.

3) Help in creating an awareness of conservation in society, with special regard to the sustainable management of natural resources.

Activities

1) Presentations at workshops for educational institutions, oriented towards different education and age levels and involving different activities on a case-by-case basis.

2) Production of a brochure for dissemination, with basic information regarding the species and the threats and problems it currently faces.

3) Development of a poster with an image of the species and a clear, simple message about the need to help protect it.

4) Development of a study guide for students that includes information and activities for every educational level (basic information on cetaceans, the franciscana, its habitat and problems it faces with conservation; also crossword puzzles, word searches, puzzles, questionnaires, and various other games).

5) Creation of a certificate for schools that includes the unit in their studies, which says that their school has helped preserve the franciscana.

6) Campaign to disseminate information about the conservation project of the franciscana generally through various media.

Activity 4 will be introduced at schools where presentations and workshops are given.

Activities 2 and 3 will be used in the dissemination campaign as well as in schools where presentations and workshops are given. 